\title{
KRONIK
}

\section{Milosevic Lahey Yolunda}

Yrd. Doç. Dr. Gökçen Alpkaya, A.Ü. Siyasal Bilgiler Fakültesi Öğretim Üyesi

Eski Yugoslavya için Uluslararası Ceza Mahkemesi (tam adı 1991'den beri eski Yugoslavya Topraklarında Gerçekleştirilen Ağır Uluslararası Insani Hukuk thlallerinden Sorumlu Kişilerin Kovuşturulması Için Uluslararası Mahkeme) Savcısı, Yugoslavya Federal Cumhuriyeti Devlet Başkan Slobodan Milosevic hakkındaki iddianamesini 22 Mayıs 1999'da sundu. Uluslararası Mahkeme'nin usul kurallan uyarınca bir yargı̧ tarafından gözden geçirilen iddianame 24 Mayıs'ta onandı ve Milosevic sanık statüsüne geçti.

Bir devlet başkanun, üstelik hâlâ devlet başkanı olduğu sırada "sank" haline getirebilen Uluslararası Mahkeme, BM Güvenlik Konseyi'nin 25 Mayıs 1993 tarihli ve 827 (1993) sayılı kararıla kurulmuştu. Güvenlik Konseyi, Mahkemeyi, eski Yugoslavya'da yeni ulus-devletlerin kurulması sürecinde işlenen uluslararası suçlan kovuşturmakla görevlendirdi. Bu suçlar, Güvenlik Konseyi kararına ekli Mahkeme Statüsünde, 1949 Cenevre Sözleşmelerinin ağır ihlalleri, savaş yasa ve geleneklerinin ihlalleri, soykırım ve insanlığa karşı suçlar olarak tanımlandı. Bunlar, suç olarak tanımlanmaları görece yeni olsa da, aslında ulus devletlerin kuruluş sürecinde işlenmeleri neredeyse kural haline gelen, tanıdık eylemlerdi.

Uluslararası Mahkeme'nin, gerck suç tanımı, gerekse ceza sorumluluğunun bireylere yüklenmesi bakımından, Nürnberg ve Tokyo deneyiminden önemli bir kopuşu temsil ettiği pek söylenemez. Ama, kuruluş biçimi bakımından, adeta bir devrimi simgelediği söylenebilir, söylenmelidir. Bu ad hoc mahkeme, "uluslararası topluluk" adına hareket eden, bu yetkiyle daha 1945 'te donatılmış olan BM Güvenlik Konseyi'nin, adına hareket ettiği topluluğun yüzlerce yıldır sahip olduğu varsayllan egemenlik yetkilerinden birini, hem belki de en önemlisini, yargılama ve cezalandırma yetkisini devralmasının simgesidir.

Güvenlik Konseyi, Uluslararası Mahkeme'yi, BM Antlaşması'nın VII. Bölümüne dayanarak kurdu. Ne Güvenlik Konseyi kararında, ne de Genel Sekreter'in karara ekli raporunda, Güvenlik Konseyi'ne bu yetkiyi hangi maddenin verdiği belirtilmişti. Uluslararası Mahkeme ise, Tadic Davası'nda, kendi yetkisini sorgularken, minarcyi çalan kendisi olmadığı halde, kılıfı hazırlayıp, kendisinin 41. maddeye dayanılarak kurulduğuna karar verdi.

Bir ad hoc mahkeme kurma kararı, genellikle, Konscy'in Soğuk Savaş'ın sona ermesiyle birlikte, BM Antlaşması'nın VII. Bölümü altnda sahip olduğu 
zorlayıcı yetkileri kullanmak üzere başvurduğu yaratıcı, yenilikçi önlemlerden birisi olarak değerlendirildi. Yugoslavya dışında hiçbir devlet, Uluslararası Mahkeme'nin kuruluşuna karşı çkmadı, aksine, bütün devletler, en azından Genel Kurul'da Mahkeme bütçesini onaylayarak, yargıçları seçerek Mahkemeye destek verdi. Öğretide de Uluslararası Mahkeme'nin kuruluşunun bir sorun olarak ele alınmadığı söylenebilir: Klasik devletler hukuku teorisinin sonunu ilan eden bu gelişme, güçlü ama çok az sayıdaki teorik eleştiri dışında, öğretinin neredeyse tamamı tarafından, pek de sorgulanmadan olumlandı.

Uluslararası Mahkeme'nin yukarıda belirtilen suçlan yarglama ve cezalandırma yetkisiyle donatılması, bu suçlan işleyenlerin cezasız kalmamasını sağlamanın ötesinde bir önem taşıyor: Devletler, sadece eski Yugoslavya ülkesinde kurulanlar değil, yeryüzündeki bütün devletler, Uluslararası Mahkeme karşısında yükümlülük altındalar. Bunun hukuksal dayanağı, BM Antlaşması'nın VII. bölümü ve buna dayanılarak alındığı belirtilen 827 (1993) sayılı karar. Bu kararda, devletlerin Uluslararası Mahkeme karşısındaki yükümlülüğü açıkça dile getiriliyor; buna göre bütün devletlerin, bu karar ve Statü uyarınca Uluslararası Mahkeme ve onun organlarıyla tam bir işbirliği yapması, kararın ve Statünün hükümlerini uygulamak üzere, ulusal hukuklarında gerekli bütün önlemleri alması gerckiyor. Işbirliği yükümlülüğü, Mahkemenin bağımsız bir organı olan Savcı'nın istemlerine yanıt vermeyi ve Mahkeme dairclerinin buyruk ve kararlarına uymayı içeriyor. Bu yükümlülüğ̈un yerine getirilmemesi durumunda Mahkemenin kendisinin doğrudan uygulayabileceği bir yaptırım yok, sadece bunu Güvenlik Konseyi'ne bildirebiliyor.

Uluslararası Mahkeme, kuruluşunun ilk yıllarında kendi halinde bir uluslararası birimdi. Yargıçlar seçilip Lahey'de bir sigorta şirketinin binasında çalışmaya başladıklarında, önlerinde Güvenlik Konseyi kararından başka bir şey yoktu. Eski Yugoslavya ülkesinde barışın tesisi için oluşturulan bu organ, elbette barışı tesisi edemediği gibi, işlenegelen suçları da -yine elbette- önleyemedi. Srebrenica katliamının, Mahkemenin kuruluş kararından iki, fiilen çalışmaya başlamasından bir yll sonra gerçckleştiği hatırlanırsa, bu etkisizlik kendiliğinden ortaya çıar. "Dayton Barışı"nın, Uluslararası Mahkeme'nin daha o sırada sanık olarak ilan ettiği Radovan Karadzic ve Ratko Mladic'in de içinde yer aldığı bir mekik diplomasisi ile sağlanması, anlaşmanın altında daha sonra sanık olarak ilan edilecek -ve aslında edilmesi gerektiği halde çeşitli nedenlerle edilemeyecekdevlet başkanlanıın imzasının bulunması, etkisiz bir girişime yönelik umutsuzluk duygusunu pekiştirmişti.

Ama, Uluslararası Mahkeme, uluslararası ilişkilerde yaşanmakta olan dönüşümün iç dinamiklerinin sonucuydu ve biraz da rastlantısal biçimde, bununla eşzamanlı bir gelişme göstermeyi başardı. Esas olarak 1997'den başlayarak, sınırlı ama etkili bir yargı organı olduğunu kanıtladı. Başlangıçta, 
ele geçirilemeyen sankları teşhir etmeyi sağlayan Kural 61 uygulamasıyla, aralannda Karadzic ve Mladic'in de bulunduğu "ünlü" kişilere dikkat çekti. Sonra yavaş yavaş küçük balıkları yakalamaya başladı: Omarska kampında Müslüman sivillere karşı işlediği suçlar için Dusan Tadic, Srebrenica katliamındaki nefer rolüyle Drazen Erdemovic, yargılanıp cezalandırlan ilk suçlular oldu. Ardından sıra yıldızh Hırvat generallere geldi: Tihomir Blaskic Lasva Vadisi'nde kazandığı kirli savaş nedeniyle Uluslararası Mahkeme önünde 45 yl cezaya çarptırıldı. Kısacası Uluslararası Mahkeme, yargı yetkisini, çoğunlukla suçların kim tarafından ve kimlere karşı işlendiğine bakmaksızın kullandı. Çoğunlukla ifadesi yersiz değil, çünkü Savci'nın Yugoslavya'ya NATO müdahalesi hakkında soruşturmaya gerek görmeme kararı, tartışmalı bir karar olarak tarihe geçti.

Şimdi sıra Milosevic'e geldi. Milosevic'in Lahey'de yarglanması simgesel açıdan elbette büyük bir önem taşıyor. Milosevic'i Uluslararası Mahkeme nezarethanesinde ağırlayıp gösterişli bir yargılamayla mahkum etmek, zaferi taçlandırmak anlamına gelecek. Milosevic'e yönelik iddianame şimdilik sadece 1999 başından itibaren Kosova'da işlenen suçlarla sinırlı, ama Uluslararası Mahkeme savosıı iddianameyi genişletme hazırlığı içinde. Bir yargıç tarafından onanmak koşuluyla, iddianameyi 1991 başından itibaren işlenen bütün suçları işerecek şekilde genişletmek mümkün.

Milosevic "Lahey'e ancak cesedim gider" dese de, Yugoslavya'nun Milosevic'i teslim etme olasılığı yüksek görünüyor. Ama her koşulda, Mahkeme'nin artık meşruiyetini kabul ettirmiş olduğu söylenebilir. Slobodan Milosevic hastallk ya da ölüm nedeniyle Mahkeme'ye teslim edilemese bile, bütün dünya artık Milosevic'lerin uluslararası mahkemelerde yargılanıp cezalandırılabileceğini biliyor. Bundan sonra, ulus devlet adına, milliyetçilik adına yola çıkanların bir kez daha durup düşünmesi gerekiyor: "Insanlık" adına karar verenler, artık bu suçların uluslar adına işlenmesini hoşgörmeyecek. Uluslararası Mahkeme deneyiminden çkan en önemli ders bu. 


\section{Kasım Krizinden Şubat Krizine}

Prof. Dr. Sinan Sönmez, A.Ü. Siyasal Bilgiler Fakültesi Öğretim Üyesi

Aralık 1999'da IMF ile imzalanan stand-by anlaşmasının akabinde uygulamaya konulan istikrar ve yapısal uyarlama programı çerçevesinde kamu borçlanmasın sınurlama, vadesini uzatma ve borçlanma faizlerini aşağı çekme hedefleri 22 Kasım'da patlak veren krizle birlikte de facto ortadan kalkmışttr. Hükümetin istikrarın sağlanması, bu bağlamda enflasyon hızının yavaşlatılması doğrultusunda stand-by anlaşması çerçevesinde belirlenmiş bulunan daralthcı maliye/bütçe politikası, buna uyumlu para-kur politikası ile gelirler politikası uygulamış ve "yapısal reformlar" olarak nitelendirilen, "serbest" piyasa düzenine uyarlanma yönündeki değişiklikler başlatılmış olmasına ve bu yönde belirli bir mesafe alınmış bulunulmasına rağmen kriz ortaya çıkmıştır.

Kriz oluşumunda 1983 sonrasinda giderek artan iç borçlanma, 1989'da gerçekleştirilen finansal serbestleşme, bu temelde yükselen faiz-kur arbitrajından sağlanan ve vergi dışı tutulan kazançlar, kısa vadeli sermaye girişine (büyük ölçüde sıcak para) dayalı bir finansman modelinin benimsenmesi, bankacılık sisteminin zayıf ve hastalıklı yapısı, kayıtdışlığın genişlemesi, denetim cksikliği gibi etkenler ana çerçeveyi çizmektedir. Bununla birlikte Kasım 2000 ve Şubat 2001 krizlerinin olgunlaşmasında Aralık 1999 tarihinde kabul edilen IMF programının iki temel özelliğini dikkate almak gerekli gözükmektedir. Birinci özellik sıkı döviz kuru tahhüdü (döviz kuru çapası), ikincisi ise TCMB'nin Net Iç Varlıklar kaleminin sınırlanması, piyasanın fonlanmasının Net Dış Varlıklar'a bağlanmasıdır.

Kurun çapa olarak kullanımı, bu bağlamda kurun alacağı değerin takvime bağlanması kaçınılmaz olarak TL'nin aşırı değerlenmesine yol açmıştır. Sonuçta ithalat hızla artarken ihracatta tıkanıklıklar oluşmuş, giderek genişleyen dıs ticaret açığı cari açığın 2000 yilı sonunda öngörülenin yaklaşık dört katına ulaşmasına ( 9.765 milyar dolar) yol açmıştır. Böylece IMF programı öncesinde mevcut olmayan cari açık ve finansman sorunu ortaya çımıştır. Stand-by anlaşması ile TCMB'nin Net İ̧ Varlıklar kalemine kısıtlama getirilmesi, Banka'nun para politikası araçannı kullanarak piyasanın likidite ihtiyacını karşılamasını engellemiştir. Çünkü emisyon için Net Uluslararası Rezervlerin artırılması gereklidir. Söz konusu rezervler TCMB'nin stokladığı altın ve döviz miktarından brüt uluslararası yükümlülüklerin çıkarılmasıyla elde edilmektedir. Emisyonu olanaklı klan parasal taban genişlemesi ise Net Uluslararası Rezervlerin pozitif değere sahip olmasıyla olanakııdır. Net rezerv artı̧ı Hazine ve bankaların TCMB'ye döviz satışı ile olanaklı kılınmaktadır. Kısaca modelin/sistemin işlerlik kazanması için Hazine'nin dış finansal piyasalardan borçlanması, dıs yatıımlar aracılığıyla yabano sermaye girişinin olması, döviz 
girişi sağlayan özelleştirmeler gereklidir. Gene dikkate alınması gerekli diğer koşullar arasında cari açı̆̆ın finanse edilebilir bir düzeyde seyretmesi ve bankacilık sisteminin döviz/TL cinsinden likit kalmasl, yani yükümlülüklerini aksatmadan yerine getirmesi bulunmaktadır. Yukarıda ana hatları ortaya konulan model, döviz rezervlerinin dış borçlanma pahasına neden yüksek tutulmaya çalışıldığını açıklamaktadır.

Kasım 2000 krizi yukarıda belirtilen koşulların bir araya getirilememesinden kaynaklanmıştur. Özellikle dıs ödemeler dengesinde, cari açıktaki patlama ile somutlaşan istikrarsızlık ve çalkantı, huzla finansal piyasalara yayılmıştır. Bu bağlamda 1989 'da gerçekleştirilen finansal serbestleşme ile faiz ve döviz kurunu politika araçları olarak etkin biçimde kullanma olanağını yitiren TCMB'nin pasif konuma itilmesi operasyonunun, 17. stand-by anlaşması ile Net İ̧ Varlıkların dar bir bant içine sıkıştırılması ile tamama erdirilmesinin krizin çok önemli bir öğesini oluşturduğunu bir kez daha anımsayalım. Nitekim Kasım 2000'de bankaların likit olmaması krizi tetiklemiştir. Ancak likidite darlığın bankaların zaman içinde oluşan hastalıklı ve kırılgan yapıların dikkate alarak çözümlemek gerekiyor. Bir kez bankalar gerçek bankacilık faaliyetlerinden uzaklaşıp DlBS (Devlet Iç Borçlanma Senetleri) ticaretine odaklandıkları, yetersiz sermaye tabanına sahip oldukları, kredi riskini ölçme ve değerlendirmede gerçekçi olmadıkları, ortaklarına ve bağlı şirketlere aşırı kredi kullandırdıkları, aşın derecede vade uyumsuzluğuna sahip olduklan ve kısa vadeli dış borçlanmanın yol açtığı aşırı (nct) açık pozisyona sahip oldukları ölçüde kırılgan bir yapıya sahip olmuşlardır. Sorunlu olan bankalar portföylerindeki DiBS'leri TCMB'ye daha sonra geri almak üzere satarak likidite sağlamalarının sınırlandırımıs olması nedeniyle, çok yüksek faiz üzerinden repoya yönelmişlerdir. TCMB ise stand-by anlaşması gereği bankalara açtığı kredi ve API (Açık Piyasa Işlemleri) hacmini genişletememiştir. Bununla birlikte Korkut Boratav'ın değerlendirmesiyle likidite krizi tümüyle yabanc1 ve yerli aktörlerin "sıcak" sermaye hareketlerinden oluşan, borsadan yurtdışına çıkışlar, yenilenmeyen kısa vadeli dış krediler, borৎ̧ senetlerinin dolara çevrilmesi ve diğer yerli varlıkların dolara ve kısmen yurtdışına yönelmelerinden ve on gün içinde net dış varlıklarda ve TCMB rezervlerindeki erimeden kaynaklanmıştır.

Kasım'daki kriz sürecinde IMF'nin onayı ile TCMB bankalara API ile TL cinsinden likidite sağlamış, bir başka deyişle bankalarla repo yapmıs, böylelikle belirli bir süre için Net Iç Varlıklarını artırarak emisyona gitmiştir. Bankalar TL cinsinden likiditeyi kullanarak TCMB'den döviz almışlar, sonuçta Banka'nın büyük ölçüde borçlanma yoluyla elde ettiği net uluslararası rezervleri önemli ölçüde erimiştir. Krizin patlak vermesinin ardından Ankara'ya "çapa atmış" olan IMF heyeti ile sürdürülen görüşmeler sonucunda Türkiye'ye IMF'nin Ek Rezerv Imkanı kapsamında 7.450 milyar dolar, Stand-by çerçevesinde 1.670 milyar dolar olmak üzere toplam 9.120 milyar dolar tutarında bir destek vermesi 
konusunda anlaşma sağlanmıştır. Dünya Bankası ise Ülke Yardım Stratejisi kapsamında 1.028 milyar dolar (778 milyon dolarlık kısmı kamu bankalarının özelleştirilmesi temel koşuluna dayalı Mali Sektör Kredisi, 250 milyon dolarlık kısmı ise Özelleştirmeye Sosyal Destek Programı çerçevesinde verilen kredidir), kamu bankalarınin yeniden yapilandırılmasına Destek Kredisi olarak da 500 milyon dolarlık kaynağı BDDK'ya tahsis etmeyi kabul etmiştir. Kriz sürecinde dikkate alınması gerekli husus ise 18 Aralık 2000 tarihinde kaleme alınmıs olan üçüncü ek Niyet Mektubu'nun içeriğidir. Avrupa Bölge Direktörü Deppler 6 Aralık tarihindeki basın toplantısında krize karşı alınan önlemleri açıklarken, MF yetkililerinin bizzat kaleme almış oldukları aşikar olan yeni Niyet Mektubu'nun özünü de gözler önüne sermiştir. Toplam 62 maddeden oluşan Niyet Mektubu'nda mevcut maliye/bütçe, para/kur ve gelirler politikasının kararlılıkla sürdürüleceği belirtilmektedir. Ilginç bir husus da 6 Aralık'daki basın toplantısında mevduat garanti sisteminin sürdürülmesinin yanısıra yabancı bankaların Türkiye'deki bankalara açtıkları kredilerin hükümetin güvencesi altında olduğunun açıklanmasıdır. Bu açıklama Niyet Mektubu'nda "hükümetin,..., yerel bankalardaki mevduat sahiplerini ve bu bankaların diğer kreditörlerini tamamen garanti altına aldığı" biçimiyle resmileştirilmiştir. Niyet Mektubu'nun çarpıc özelliği "yapısal reformlar" bağlamında çok ayrıntılı bir özelleştirme programı ile takvimine yer verilmesidir. Mektupta Elektrik Piyasası Kanunu'nun 2001 Ocak sonuna kadar çlkanlacağı, Türk Telekom'un, güçlü yönetim hakkı devriyle birlikte hisselerinin \% 33.5'inin stratejik yatırımclara satışının 2001 Mayıs sonuna kadar tamamlanacağı, THY'nin \% 51'inin 2001 Mart sonuna kadar özelleştirileceği, enerjide 29 YID projesinin 31 Aralık 2000 tarihine kadar ilan edileceği, TEKEL'in özelleştirilmesine ilişkin kararın 2001 Ocak sonuna kadar alınacağı, tarım kesimine verilen dolaylı destek politikasından 2002 sonuna kadar kademeli olarak vazgeçileceği ve doğrudan gelir desteği sisteminin uygulanacă̆ı belirtilmektedir. Bu bağlamda şeker pancarı alım ve işlemesi ile ilgili KIT olan TŞFAŞ'nin en az altı şeker fabrikasının 2001'de, geri kalanların 2002 sonuna kadar özelleştirileceği, Şeker Kanununun en geç 15 Mart 2001, Alkollü Içkiler Kanunu ile Tütün Kanununun 2001 Ocak sonuna kadar çkarlacağı taahhüt edilmektedir.

Aralık $2000^{\circ}$ de yapılan düzenlemelerden 19 Subat 2001 tarihinde beliren krize uzanan kesitte, 1999 Aralık ayında alınan önlemlerin ve iktisat politikası araçlarının daha da güçlendirilerek uygulanmasına devam edilmiştir. Bu bağlamda enflasyonu aşağı çekmek doğrultusunda kamu kesiminde temel fazla ile konsolide bütçede faiz dışı fazlanın elde edilmesine yönelik dar bütçe/maliye politikaları, sıkı döviz taahhüdüne dayalı para politikası ve gelirler politikası sürdürülmüş, özelleştirme doğrultusunda düzenlemeler yapılmıştır. 2001 yılı için GSMH artışı \% 4.5 , GSMH deflatörü \% 18, yıl sonu itibariyle TEFE \% 10 , TÜFE \% 12, yıllık ortalama dolar kuru 715 bin TL, cari işlemler açığının GSMH'ye oranı \% 3.1 olarak belirlenmiştir. Yaklaşık olarak 48.4 katrilyon T.L. 
olarak belirlenen bütçede faiz dışı fazla 11.447 katrilyon TL olarak öngörülürken, bütçe açığının hızla azalarak 5.233 katrilyon TL'ye ineceği tahmini yapılmıştır. Bir başka deyişle bir önceki yil \% 37.3 olan bütçenin GSMH'ye oranı, \% 31.5'e çckilmiş, faiz dışı giderlerin GSMH'ye oran ise \% 0.3 'lük bir azalmayla \% 20.7 olarak belirlenmiştir. Faiz dişı fazla 2000 yılı gerçekleşme tahminlerine göre yarım puan artırılarak \% 7.5 olarak belirlenmiştir. Faiz ödemelerinin GSMH'ye oranı \% $10.9^{\prime}$ da tutulurken, personel ödemelerininki \% 7.8, yatırımlanınki ise \% 2.3 olarak saptanmıştır. Sosyal güvenlik kurumlarına yapılacak ödemelerin payı değiştirilmeksizin \% 2.8'de tutulmuştur. 2001 yılı bütçesi bütçe/maliye politikalarının daraltı́ yönünü açıkça gözler önüne sermektedir; faiz ödemeleri bir başka "çapa" olmakta, faiz dı̧ı fazlanin yüksek tutulmasına uygun olarak reel harcamalar düşük düzeyde bırakılmaktadır. Finansman yönünden özelleştirmeler ve vergiler ile toplam 43.1 katrilyon tutarında bir gelire ulaşılacağı, açığın 4.8 katrilyon liralık kısmının iç borçlanma, 0.4 katrilyonluk kısmının da dıs borçlanma ile finanse edileceği kurgusu yapılmıştır. Bir başka deyişle 38 katrilyon TL dolaylarında borৎ̧ geri ödemesi yapılacağı için, 28 katrilyon liralık iç borçlanma, 7.5 milyar dolar tutarında da diş borçlanma hedeflenmiştir.

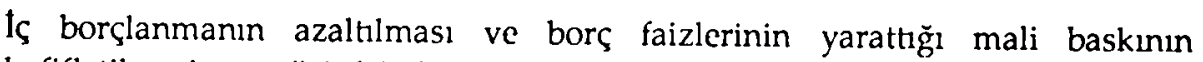
hafifletilmesi stratejisi, faiz hadlerinin aşağı çckilmesi ve dış finansmana ağırlık verilmesi düşüncesine dayanmaktadır. Oysa Kasım krizinin yol açtı̆ı dengesizlik tüm hesapların yeniden gözden geçirilmesini gerektirmekteydi. Dengesizlik ve belirsizlik ortamında Hükümet IMF ve Dünya Bankası'ndan takvime bağlı olarak elde edeceği dış finansmana dayanarak mevcut anti-enflasyonist ve yapısal uyarlama programın uygulamayı sürdürmüş, 2001 'e ilişkin makro göstergeler ve bütçe hedefleri gerçekçi olmayan bir biçimde belirlenmiştir. Böylece Kasım 2000'de yaşanan kriz geçiştirilmiştir. Dengeler oluşturulurken Kasım krizinde tavan yapan faizlerin \% 30'lar düzeyine sckilmesinin ve/veya bu düzeyin uzun süre korunabilmesinin güç olduğu, finansal krize bağlı olarak bilançoları bozulan bankaların dışarıdan borçlanmalarının giderek güç hale geldiği, enflasyonda belirli bir düşmenin kaydedilmiş olmasına karşın saptanan hedeflerin aşıldığı, bankaların kamu kağıtlarına yönelmeleri için devlet iç borçlanmasında uygulanan faiz hadlerinin yukarı çckilmesinin kaçıılmaz olduğu ve böylelikle enflasyonist baskının artacağı, dıs finansmanın giderek zorlaştığı, krize rağmen döviz kuru üzerindeki baskının TL'deki aşırı değerlenmeyi sürdürdüğ̈̈, piyasanun fonlanmasında TCMB'nin pasif konumunun sürdürülmesinin ve borçlanma yolu ile net uluslararası rezervlerin artırılmasının, kısa vadeli sermaye hareketlerinin hiçbir biçimde denetlenmediği bir ortamda yüksek riziko arz ettiği, TMSF'ye alınan özel bankaların zararlarının giderek arttığı ve finansman ihtiyaçlarının büyük boyutlara ulaştı̆̆ı dikkate alınmamıs ve/veya göz ardı edilmiştir. Nitekim 30 Ocak 2001 tarihli yeni ek Niyct Mektubu'nda mevcut para politikasının 
sürdürüleceği, 31 Ocak tarihinden sonrası için Net tç Varlıklar üst sınurının aşağı, Net Uluslararası Rezervleri alt sınırının da yukan çekildiği vurgulanmaktadır. Gazi Erçel'in 5 Şubat 2001 tarihli "Enflasyondaki Gelişmeler ve 2001 Yllına Bakıs" başlıklı basın duyurusunda da ekonomik-finansal bozukluklar dikkate alınmaksızın iyimser bir değerlendirme yapılmaktadır. Erçel enflasyonda Ocak ayında gerçekleştirilen rakamların programa olan güveni tazelediğini, $2001 \mathrm{y} \mathrm{l}_{1}$ enflasyon hedeflerinin erişilebilir olduğunu belirtmektedir.

Kasım'da geçiştirilen finansal kriz 19 Şubat 2001 tarihindeki siyasi kriz ve/veya gerginlik ile daha şiddetli olarak üzere yeniden ortaya çıkmıştır. Siyasi kriz olgunlaşmış olan finansal krizin bahanesi veya ateşleyicisi olmuştur. Siyasi krizin çımaması durumunda, finansal kriz 19-22 Subat aralığından daha sonraki bir tarihte mutlaka patlak verecekti. Siyasal kriz finansal çöküşün tarihini yalnızca öne almıştır. llginç olan nokta da 19-20-21 Şubat tarihlerinde Hazine'nin önemli borç ihalelerinin olmasıdır. Enflasyonun aşağı çekilmis olmasına rağmen, kriz öncesinde Hazine iç borçlanmasının \% 20 dolayında reel faiz sağlayacağı yönünde bir beklentiye girilmesi de sistemin kırılganlığını ve güvenilir olmadığını işaret eden önemli bir göstergedir. Krizin ortaya çıkışı ele alındığında bankalar ve yabancı yatırımcıların TL pozisyonlarını dövize çevirerek yurtdışına çıkarmaya başladıkları gözlenmektedir. 7.6 milyar dolara ulaşan döviz çıkışıın ardından, TCMB'nin repo ihalesi yoluyla piyasaya TL vermeyeceğini açılklaması üzerine, bankalar TL'ye dönmeye başlamı̧ ve döviz girişleri 4.3 milyar dolara ulaşmıştır. TCMB'nin piyasaya TL vermemesi IMKB repo piyasasında gecelik faizin 21 Şubat'ta \% $7500^{\circ} \mathrm{e}$ tırmanmasına yol açmıs, interbank piyasasında gecelik faiz de \% 6200'e fırlamıştır. Bankaların müşterileriyle yaptıkları repolarda ise faiz \% 500 ün üzerine çıılmışır. Borsada ise \% 18.11'lik bir düşüs kaydedilmiştir. TL'ye talebin artıp, repo ve interbank piyasasında gecelik faizlerin patlama yaptığı bir ortamda, bankalar yeniden dövize yönelmişler ve aynı gün TCMB'den yeniden 3.1 milyar dolar satın almışlardır. Bu finansal karmaşa içinde Hazine 7 ve 12 aylık ihaleleri bir ay vadeli ihaleye çevirmiş ve ihalede \% 144.2 faizle 1.5 katrilyon TL tutannda satıs yapmıştır. Durumun kontrolden çıkması üzerine ekonomi üst bürokrasisinin de katıldığı toplantı sonunda Hükümet, uygulanan politikaya devam edileceğini ancak "kur çapası" uygulamasına son verildiğini ve "dalgalı kur" sistemine geçildiğini açıklamıştır.

TCMB'nin piyasaya likidite sağlayamadığı, döviz kurunu değiştiremediği, faizlere müdahale edemediği, kısaca Banka'nın kur ve para politikası araçlarının elinden alındığı, maliye/bütçe politikasının borç yönetiminin peşinden sürüklendiği veya biçimlendirildiği bir modelde enflasyonun aşağı çekilmesi yönündeki uygulamaların ckonomik, finansal ve sosyal faturası çok ağır olmuştur. İşin ilginç tarafı da Başbakan IMF modelinin sürdürüleccği yönünde 
açıklamalarda bulunurken, IMF'nin izlediği yöntemlerin ve işleyişin çağın gerisinde kalmış olduğu yönündeki eleştirilerin ABD'de bile yapıldığına ilişkin görüş bildirmesidir (Milliyet, 8 Mart 2001). Başbakan Yardımcısı Ylmaz ise bir adım daha atarak "Bu program Türkiye'nin mali sistemin yapısını doğru biçimde ele alan bir program değildi. Program çökmüştür" yargısında bulunmuştur (Hürriyet, 9 Mart 2001). Çöktüğü bizzat başbakan yardımcısı tarafından kabul edilen modelin yalnızca kur ayağı radikal biçimde değiştirilerek özü ve diğer araçları korunarak yeni bir "süper bakan"a ekonomi ve program teslim edilmiş gözükmektedir. 